\title{
READERS
Insight
}

Journal of Management Info (JMI)

ISSN:2313-3376

www.readersinsight.net/jmi

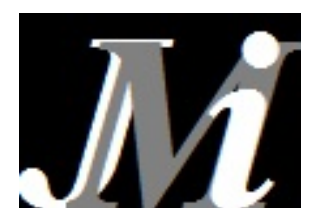

\section{Applying managerial competencies to overcome business constraints and create values: Evidence from small technology-based firms in Malaysia}

\author{
Amran Rasli ${ }^{1}$, Nadhirah Norhalim², Tan Owee Kowang ${ }^{3}$, Muhammad Imran Qureshi ${ }^{* 4}$ \\ ${ }_{1,2,3,4}$ Faculty of Management, Universiti Teknologi Malaysia (UTM), Skudai Johor, Malaysia
}

*Corresponding author: miqureshi80@gmail.com

\section{Abstract}

Study analyzed how technology based frims apply resource-based theory of organizational competitiveness in Malaysia. Data has been collecteted through in-depth interviews, document review and observation. A sample of 13 companies has been adopted for study. The interplay of value creation and managerial competencies as the drivers of competitiveness to overcome business constraints with the perspective of time has been studied. Study investigate three different types of organizational compitencies required to adress four type of organizational constrains which limitize value creation process in the organization. There are few firms which demonstrate the capabalities to compete globally. We propose that Malaysian companies embrace the concept of learning culture to be the driver for the attainment of high value added value creation and managerial competencies whilst overcoming the business constraints faced.

\section{ARTICLE INFORMATION}

Received: 25 March 2015

Revised: 25 June 2015

Accepted: 25 June 2015

DOI:

http://dx.doi.org//10.31580/jmi.v3i1.15

\section{Introduction}

Value creation is focal concern among paractioners over the years. Researchers investigated several measures of conceptmainly There are two measures of value creation, with respect to both customers and investors perspectives. customer's perspective of value creation entails making products and providing services that customers find consistently useful, while investors perceptive of value creation means maximize returns on investment (O'Malley, 1998).

The value creation is a continious process having four distinct phases, first phase starts with an understanding of the customer's requirements, second phase exploring areas for improvement, at phase three possible solutions are defined and phase four consist of prioritizing opportunities (refer Figure 1).At first phase customer's requirement and priorties should be asscessed through inteaction with customers. , identify competitors in the value network. According to Prahalad et al. (2004) consumers are increasingly engaged in both defining and creating value, co-creation experience of consumer becomes very basis of value. In other words, the "most basic change has been a shift in the role of the consumer-from isolated to connected, from unaware to informed, from passive to active. The impact of this new-age consumer is evident in the areas of information access, global view, networking, experimentation, and activism (Prahalad, et al. 2004). The second phase of the value creation process involves exploring areas for improvement requires coordination with other agencies, businesses, suppliers and the customers to determine how to fulfil the customer's needs as well as to determine whether there is potential to work together on solutions identified. The third stage is to define possible solutions by working with value network partners to define solutions and to establish set of workable solutions scenarios. Finally, companies have to focus by prioritizing the opportunities identified by ranking scenarios based mutually agreed criteria, establish solutions to pursue and develop plans and targets to proceed with the solution (refer Figure 1). 


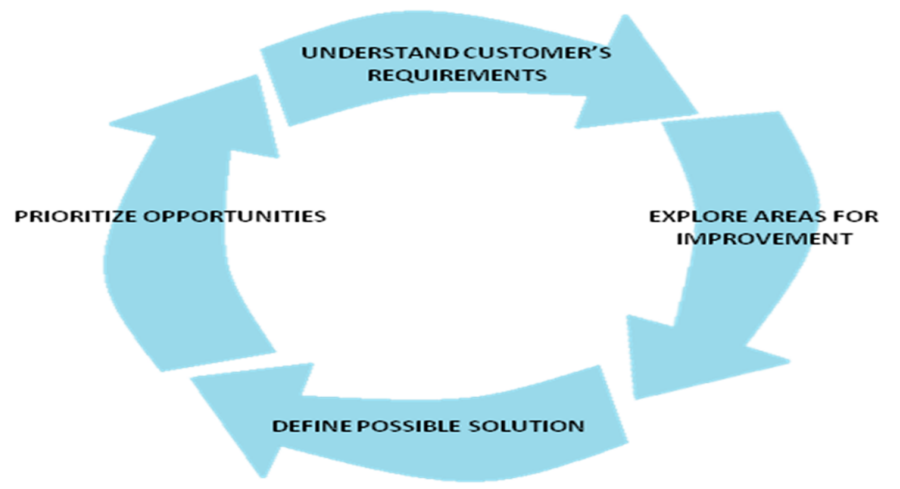

Fig. 1. The Value Creation Process

The researchers believe that value of products and services today is based more and more on creativity - companies should find the innovative ways to optimize use of new materials, technologies and processes, particularly to create innovation out of research and development lab and mainstream it. Literature highlighted two distinct causal mechanisms for explaining how firms create economic rents; resource picking and capability building Barney, J. B. (2001). Under resource picking mechanism, managers gather information and analysis to outsmart resource market in selecting resources. In this approach managers tries to acquire resources suitable for value maximization capability building perspective encourages managers to design and construct organizational systems that enhance value creation potential resources the firm.

Identification on resource picking and capability building constitutes a stronger theoretical foundation for understanding value creation than the popular "chain" metaphor Nonaka, I. (1995) . However Hunt and Morgan suggest that limiting the process to two types of activities fails to capture all of the opportunities and responsibilities of managers in the customer value creation process Nonaka, I. (1995). These authors present a model consisting of five stages, first two of which subsume Makadok's resource picking and capability building mechanisms Barney, J. B. (2001). The five stages/dimensions are depicted in Figure 2.

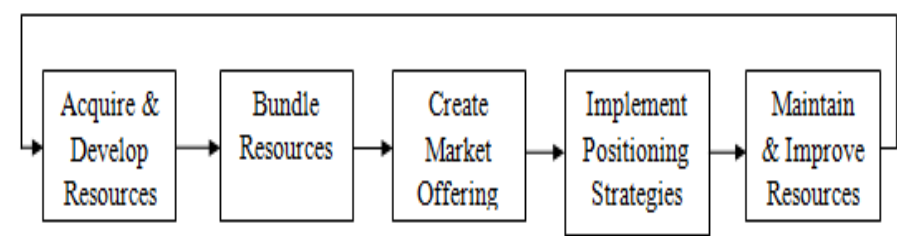

Fig. 2. R-A Model of Value Creation Nonaka, I. (1995)

This model of firm value creation shares affinities with a broad array of key literatures in strategy, especially those relating to the dynamic processes through which firms learn and compete via unique competences. Specifically, the first two stages of Hunt and Morgan's R-A Model of Value Creation; resource acquisition and develop meant and resource bundling, are classified as competence building. Next are the two knowledge exploitation activities; creating the market offering and developing and implementing positioning strategies, which these processes are categorized as competence leveraging Nonaka, I. (1995). The final process is maintaining and improving resources which were categorized as competence renewal. On the other hand, management competencies, particularly within technology-based companies contain seven component categories. Five involve understandings of core phenomena, intellectual disciplines, various technologies, and classes of products and services. Two involve functional, technological, and integrated skills. Importantly, during their use, the understandings and skills within competencies dynamically interact with one another, powerfully supporting corporate competitiveness (Edgar and Lockwood, 2008). As shown in Figure 1, there are four basic steps in the value creation process: (1) understanding customer requirements, (2) exploring areas for improvement, (3) defining possible solutions, and (4) prioritizing opportunities. This process demands that the Department, its customers, and other organizations serving the same customers work together to identify service requirements collectively. Pies and Beckmann and Hielscher (2010) identified value creation, management competencies, and global corporate citizenship as crucial to foster effective business leadership and corporate social responsibility in the era of globalization. First, the purpose of business in society is value creation whereby companies have a social mandate to organize mutually advantageous cooperation. Second, business ethics should teach the management competencies necessary to fulfil business's societal mandate. These competencies are optimization competence in the basic game of value creation, governance competence in the meta game of (political) rule setting, and the three discourserelated skills of orientation competence, reception competence, and communication competence necessary for engaging in the meta-meta game (Pies and Beckmann and Hielscher, 2010). In addition to a firm's accessibility to resources, Chandler and Hanks (1994) argue that business 
performance is also a function of managerial competencies. This view is supported by O'Dwyer and Ryan (2000), Down (1999), Kelliher and Henderson (2009) and Greenbank (2000) in their studies on micro-firms.

\section{Methodology}

A startified sample of 13 Technology based companies have been taken for the current study. Qualitative data has been collected through in depths interview. (the target companies were companies with less than 50 employees) at their premises from 26 August till 12 September 2013. The main objective of this study is to reviel how value creation relates to managerial competencies. Study also use secondary data collection techniques for investigation of facts, by studying selected documentations (such as historical records of the companies, audited reports and certifications attained), also researcher review operations of the companies. Each company has been assign a code acording to time company has been visited. This is a precoutionary measure To protect identity of companies, , i.e. Company A is the first company and Company $\mathrm{M}$ is the last company visited. Grounded in resource-based view of firm (Wernerfelt, 1984), which argues that organizational resources or assets are bundled together and interdependent or dependent upon operational competencies of firm especially with respect to technology based companies in Malaysia. Strategic management researchers operating within the resource-based view of the firm have recognized that internal stakeholders such as top management may be in a position to appropriate rents or values associated with resource-based competitive benefits (refer to seminal works by Peteraf, 1993; Lavie, ;2006 and Grant, 1991). However, most studies using resource based view are focussed on big corporations and are quantitative in nature, but current study focussed on application of qualitative instruments to investigate the interplay between value creationand managerial competencies could provide contextual informationso the study is very relavant and timely and enables practioners to understand epistomological facts rather than emprical evidences.

Applying resource-based view, researchers argue that firms possess technological resources enable them to achieve competitive advantage, that leads to superior long-term value creation Newbert, S. L. (2007), Wade, M. and Hulland, J (2004). Resources optimization can provide sustainable competitive advantage to the extent that the firm is able to protect against resource imitation, transfer or substitution.

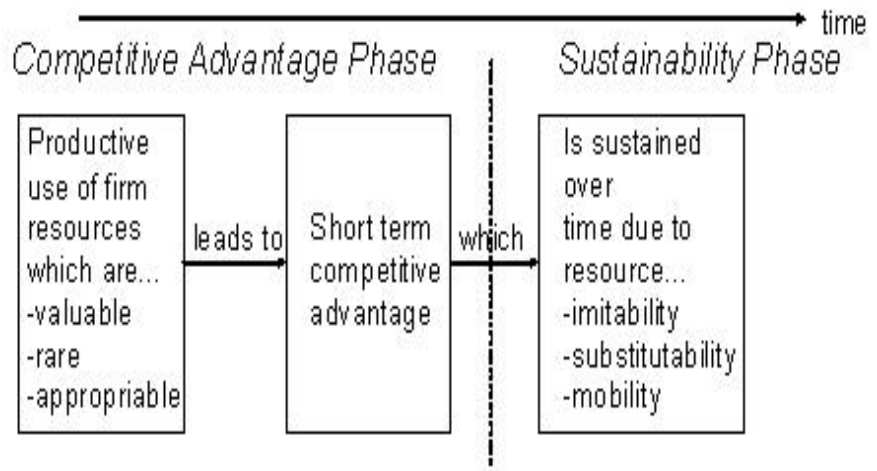

Fig. 3. The Resource Based View Over Time Wade, M. and Hulland, J. (2004)

Interview data collected has transribed following which common themes and patterns were identified using technique proposed by Miles and Huberman. Further analysis based on three stages, first data reduction. Data collected from in-depth interviews has adaquite abality to generate deductive knowledge. Apropriate data reduction techniques has been employeed in current study. The researchers followed through with "data reduction" process of selecting, focusing, simplifying, abstracting and transforming data that appears in the reported notes (refer Figure 4). Second stage of analysis consists of data display, researchers organized and compressed assembly of available information that consents to the last stage of analysis which is conclusion drawing Miles M.B. and Huberman, M.A. (1994) Figure below highlights analysis process of the study.

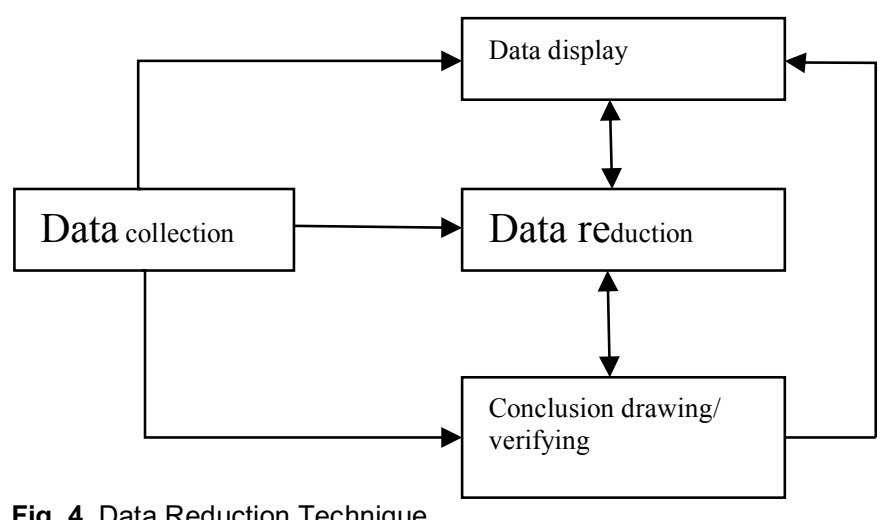

Fig. 4. Data Reduction Technique

\section{Findings}




\section{Value creation}

Researchers reviels that value creation could be clasified into three major categories: (1) basic value creation, (2) intermediate value creation, and (3) advance value creation.

Basic value creation has little impact on entrepreneur, company and community. Among those which we are able to identify include profit (which is apparent among all of the companies albeit some companies are now doing well while many are still struggling) and job creation (some companies demonstrate centralized operations while, many are trying to decentralizing now, employing between 30-50 workers and a few have more than 100 employees). Critical basic value creation in the form of enhancements of their internal research and developmentcapabilities has demonstrated by most of the companies which have been visited with exception. The final value creation is direct benefit given to customers based on services or products provided by companies. Among notable mentions include Artificial Insemination (AI) services for bovine rendered by Company A and high fibre biscuits for diabetics by Company B. Intermediate value creation has reltivly more impact on entrepreneur, company and community. Mostly those companies are able to create intermediate value who demonstrate high levels of perseverance and resilience, and are fronted by seasoned entrepreneurs. This value creation allow them to to penetrate overseas market (e.g Company $\mathrm{C}$ to Indonesia and Thailand, Company D to Europe, Company E to China, Turkey and Kazakhstan, Company $\mathrm{F}$ to China, Company $\mathrm{G}$ to Indonesia, Brunei and Saudi Arabia). Another reason to achieve this level is that these companies managed to obtain global certification such as HACCP, GMP and ISO9000 as well as Halal status as in the case of Company F, Company $\mathrm{H}$, Company $\mathrm{C}$ and Company $\mathrm{G})$. In addition, entrepreneurs expertise in relevent field could also be a factor. Some entrepreneurs are now acknowledged as experts by the government in key research areas as in the case of Company A's founder who is an expert in AI for bovine (albeit background of entrepreneur is in Geology), Company C's Group CEO for her expertise in biotechnological areas related to microbes and enzymes, and the founder of Company $\mathrm{D}$ for his extensive knowledge in orchid propagation using tissue culture. It is interesting to point out that Company $\mathrm{C}$ had successfully conducted Beneficial Microbes Symposium in 2012. Finally, a unique form of intermediate value creation was experienced by several companies in the form of "involuntary formation" of spin off companies by former staff of the companies who have acquired sufficient skills, experience and network to venture on their own as in the case of Company C and Company G. Though the involuntary spin off companies would compete directly against, high level of managerial competencies of grant recipients ensures that they are still able to attain their comparative advantage (refer Figure 2).

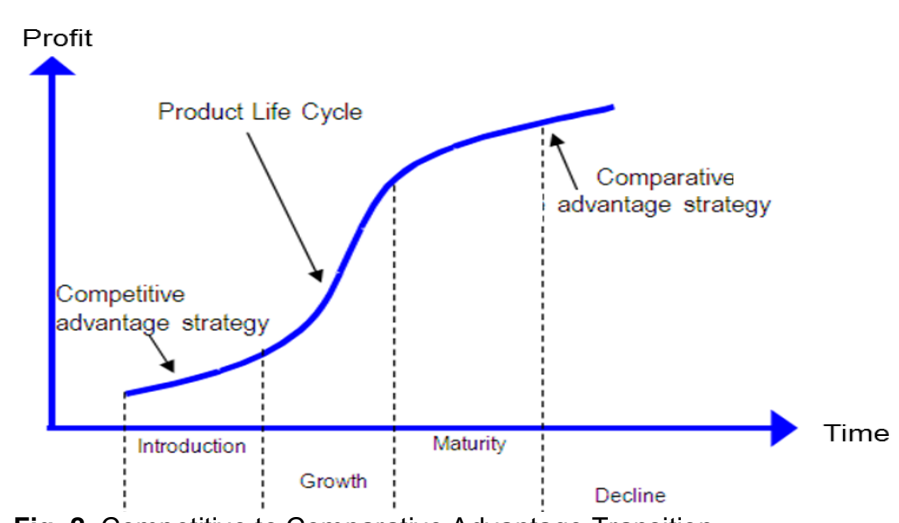

Fig. 2. Competitive to Comparative Advantage Transition

Figure 2 show a typical S-curve technology-based companies, comprise of four stages during product lifecycle. These stages are introduction, growth, maturity and decline over time. At the introduction stage, most of the companies demonstrate ability to apply competitive advantage strategy by deploying technology developments as their main "weapon". The technology that has been protected by any form of intellectual property (e.g., patent, copyright and industrial design) will ensure their technical strength as their competitive advantage over the industry. technology diffusion occur with maturity of product lifecycle and this difusion usually take place from thechnology leaders to technology

followersAdebowale, B.O.A. (2012). At this juncture, technology proliferation has occurred and most of the players in industry will have similar technology platforms accordingly. Over time also, wages and salaries rise, reflecting increasing skills of workforce. As such, to compete effectively, the "best" companies will develop comparative advantage strategies by applying best management practices in areas such as cost control, delivery excellence, superior quality control mechanisms and better people skills than the other players in the industry. We feel that only a few companies such as Company $\mathrm{C}$ and Company I have been able to reach this level (comparative advantage). These 
companies demonstrate ability to stand out among the other local companies and set standards for others to follow.

The third level is the advanced value creation. At this level, the value creation is at the maximum and could appear to be intangible. The most common form of advanced value creation is the development of new technology platforms which have been observed at many of the companies of the grant recipients. The second most common advance value creation is in the form of filing of many intellectual properties locally and abroad, this too has been observed by many of the companies. Setting up of overseas operation (e.g. production plant) has been achieved by only a few companies, namely Company $\mathrm{C}$ and Company $\mathrm{L}$ in Indonesia and Company $\mathrm{F}$ in China as the risk is high and requires intense capital outlay. Understanding of the international policies and customs is a requisite that must be fulfilled before setting up an international operation. Only one company had demonstrated ability to develop unique business models. Company $\mathrm{C}$ has developed a conglomerate or group of companies by segregating the technical and nontechnical employees into different companies. Finally, venturing into eco-friendly and/or green technology are the emerging technologies being ventured by many symbiosis companies and Company $\mathrm{C}$.

\section{Business Constraint}

During the in-depth interview sessions, the companies shared with us some of their constraints and the ways they attempted to overcome them. We presented and discussed below the identified constrain under four common themes namely marketing, finance, human resource, and research and development and technology development.

\section{Marketing Constraints}

Without good marketing strategy, even the best product will not be able to reach the consumers. Market penetration is a common and wider problem. It has found various expressions like local market is fiercely competitive; low sales record in local market; locally produced brands are perceived poor locally. All these indicate low local acceptance of locally produced brands. The case of the following companies illustrates this problem nicely.

S.I.T. Schiffs-\& Industrie Technik (M) Sdn. Bhd. is a unique case as a TAF recipient company which was able to acquire the design and technology of homogenizer from Germany. The homogenizer is an important component for ships, power plants and oil rigs. Malaysian companies, for instance, MISC the $5^{\text {th }}$ largest shipping company in the world, bought products from Schiffs-\& Industrie Technik (Germany) on a regular basis. However, these companies refused to buy from S.I.T. Schiffs-\& Industrie Technik (M) Sdn. Bhd. even though homogenizers fabricated in Malaysia are equal, if not better, to German products in terms of quality and standards. No doubt, MISC and other Malaysian companies perceived locally produced homogenizers as of poor quality. Faced with this problem, S.I.T. Schiffs-\& Industrie Technik (M) Sdn. Bhd. had to begin its sales operations through international market before venturing into the local market via a Singapore company. In fact, the company made tremendous sales in international market as the records tell: RM1.143M (2008); RM0.279M (2009); RM0.751M (2010); RM1.04M (2011) and RM1.731M (2012).

Low or no local track record also hampered export market. Significant Technologies Sdn. Bhd. for example, faced problems in marketing in Saudi Arabia because of low sales of the doublers in Malaysia. Metaxorb, a product from Malaysian Agri Hi-Tech Sdn. Bhd., faced much entry obstacles due to protectionist policies imposed by the Thailand Government. The problem of entry into foreign market coupled with the constraint of intense competition in the local market has in fact been a propelling force for many companies to innovate ways to survive and thrive. Some of these ways are briefly explained below:

Identify and target overseas market: Quite a number of companies, e.g. Malaysian Phosphate Additives Sdn. Bhd., Madura Industries Sdn. Bhd. and Malaysian Agri Hi-Tech Sdn. Bhd., are now going abroad for trade missions to identify new markets for their products. Orchid Life Sdn. Bhd. intends to buy or lease a piece of agricultural land to expand their operation and production base due to a huge demand for cut orchids from Netherland.

Production bases abroad: Some are trying to have production bases abroad due to the huge market potential. For example, Malaysian Agri Hi-Tech Sdn. Bhd. and Taiace Engineering Sdn. Bhd. have operation and production bases in Indonesia due to the huge market potential there. 
Change target market: Secuglass Sdn. Bhd. initially targeted prisons to offer them high security glass. With the same product, the company now target banks to meet their needs for bullet resistant glass.

Using better technologies to gain competitive advantage: Malaysian Agri Hi-Tech Sdn. Bhd. is now venturing into bioreactor systems to culture Ginseng and Tongkat Ali roots in a shorter time period.

Produce for significant niche market: Nourish

Care Sdn. Bhd. produces health biscuits and 3-in1 coffee based on noni fruit for diabetics. The high fiber based biscuits which are rich in beta-glucan and used natural sweeteners from Stevia, are now able to penetrate major supermarket chains. Plans are developed to produce a broader range of healthbased biscuits with better taste using ingredients such as raisins and nuts.

Moving away from a general problem of intense competition and low acceptance in the local market, we now turn to more unique companyspecific constraints and the specific ways the respective companies tried to deal with them. Export-related problem: When Malaysian Agri Hi-Tech Sdn. Bhd. first attempted to export beneficial microbes to Indonesia, mortality rate of the microbes was very high due to their exposure to the x-ray radiation during regular procedural customs inspection and clearance. This had resulted in product recall and replacement $-\mathrm{a}$ fatal blow for the company. The company was, however, not completely knocked down. It proved its determination to export by innovating and applying a creative idea. It converted the beneficial microbes into powder form and packed in aluminum foil to reflect the deadly $x$-ray radiation. Subsequently, the company set up a small processing plant in Indonesia to dilute the powder since the market demanded the microbes in liquid form. This brilliant maneuvering strategy was also able to contribute to cost savings as export in powder form is lighter and cheaper than in liquid form.

Limited product differentiation and distribution channels: Inability to create product differentiation and poor marketing channels are major sources of entry barrier. To overcome product differentiation barriers, companies often need strong innovation to create products that could leapfrog existing competitor offerings in terms of both functionality and cost. Traditional marketing outlets for Madura
Industries Sdn. Bhd. was focused on Lower Trades (Maduria brand Cola soft drinks and Asian drinks) as well as Upper Trades (Frutela Brand Fruit Flavored Cola Soft Drinks, Fruit Drinks, Juices and Teas). Being based in the East Coast caused logistic problems thus requiring Madura Industries Sdn. Bhd. to establish a new distribution center cum future site of new factory in the Klang Valley. At the same time, Madura Industries Sdn. Bhd. is now in discussion with Big Cola to be the contract packer for nationwide market; starting with 12 Stock Keeping Unit (SKU) Soft drinks, to license, distribute and market in East Coast, gain access to global raw material sourcing, enhance product Development/R\&D, improve production technology to enhance efficiency and meet cost market standard, improve branding, marketing \& distribution strategy and adopt international working culture.

With regards to the second barrier aforementioned earlier, one way of overcoming a lack of access to distribution channels is to set up your own. This can be very expensive, but it may provide the entrepreneur with a period of advantage during which you can establish your market position. Halagel (M) Sdn. Bhd. was in this position when they first started out. Taiace Engineering Sdn. Bhd. created storage products that cater to a niche market where design flexibility and a short development period are of major concern. To distribute the products effectively, Taiace Engineering Sdn. Bhd. established their own marketing unit to market and distribute their products to telecommunications and IT companies and government-linked companies.

\section{Retailer issues and high logistic costs: When} Halagel (M) Sdn. Bhd. began its business it faced high logistics costs due to the huge number of retailers spread out all over Malaysia. This problem was aggravated when most of the retailers ceased operation or could not be traced. The halal issue was advantageous to Halagel (M) Sdn. Bhd. as in the case of Ribena pastilles which used gelatin which were once made in UK by GlaxoSmithKline. But due to the halal issue, the pastilles are now produced in Malaysia by Cocoaland Industry Sdn. Bhd. which procures the gelatin from Halagel (M) Sdn. Bhd. However, Halagel (M) Sdn. Bhd. is currently importing gelatin (as raw materials) from Pakistan.

To overcome the issue of high logistics, Halagel (M) Sdn. Bhd. focused on a few wholesalers and distributors instead of many small retailers as well as 
creating their own Halagel (M) Sdn. Bhd. outlets and agents and online shopping system. Though, this strategy resulted in smaller profit margin, the assurance of volume sales and on time payment was a fair compensation accordingly.

Supply of raw materials was imported from Pakistan by Halagel (M) Sdn. Bhd. in the past. Halagel (M) Sdn. Bhd. is currently planning to build a gelatin processing plant locally to cope with the increasing demand while reducing costs at the same time. This is done by collaborating with Nutraceutical and Cosmeceutical Research Unit of UKM. Going backward in the supply chain makes it a logical progression what more with the higher import costs incurred when sourcing for raw materials from abroad.

\section{Unavailability of official standards to certify}

product: Hub Technologies (M) Sdn. Bhd. produces aerosol fire suppression system based on a foreign (Russian) technology. The system was to be certified by SIRIM before it could be ready for sale in the local market. SIRIM however could not certify the "advanced" system as it did not have fire suppression system standards. Hub Technologies (M) Sdn. Bhd. managed to solve this problem by focusing on international market first and then slowly penetrated the local market once the fire suppression system standards were made available in Malaysia. The development of such standards will provide platforms for local companies to benchmark with.

\section{Financial Constraints}

A problem common to most of the grant recipient companies is financial inadequacy. They suffer constraints like lack of resources (equipment) and funds (including working capital) that make completing the production process extremely difficult. Worst even is the case of the most Forest Research Institute Malaysia (FRIM) symbiosis companies that do not have production facilities of their own and have to operate in small incubators at FRIM in Kepong. To combat these constraints, many of them have resorted to alternative sources of finance like grants from Malaysian Biotechnology Corporation and term loans from banks. FRIM Symbiosis companies have found a solution in outsourcing the production process to contract manufacturers. Owing to financial inadequacy, procurement of high cost specialized equipment poses formidable challenge for many companies. For Rumbia Bio-
Tech Sdn. Bhd., this challenge had severely constrained its already limited advanced internal research and development facilities. This constraint had resulted in production bottlenecks and customer complaints which subsequently led to loss of sales and reputation. Rumbia Bio-Tech Sdn. Bhd. had struggled to overcome the constraint through collaborative efforts with the Agensi Nuklear Malaysia and setting up its research and development Centre within the research Centre. Financial inadequacy has also constrained operation and limited growth during initial and expansion stages. Madura Industries Sdn. Bhd. is an illustrating case for this constraint. The company faced many problems due to its inability to manage growth during the formative years when it was operating in Kuala Terengganu. The fast paced expansion due to huge demand for their products called for huge investments in equipment and facilities as well as employment of more personnel. Cash flow problems, however, crept in and caused so much financial strains on the company that it faced large number of lawsuits by suppliers. Inability to get financial support from banks had almost caused the company to cease its operation. Madura Industries Sdn. Bhd. had conquered it business-threatening problem primarily through sheer grit and perseverance. It had generated essentially required fund internally through measures like selling assets.

\section{Human resource constraints}

Employee turnover has been reported as a major problem or constraint for many of the companies. According to them, "staff-pinching" by their competitors, usually bigger in size, is the main reason for this problem. Malaysian Phosphate Additives Sdn. Bhd. is trying to overcome the problem of turnover by employing more local workers while empowering them and providing them with training. Some of the companies think that profit sharing plan could be a way to reduce the turnover of key personnel as the plan has potential to raise employee motivation and develop a higher sense of belongingness among them. In that case, the key personnel would be sharing profit with the option of converting their profit into equity participation.

Another human resource problem is employees' lost hours - a kind of employee absenteeism. As Significant Technologies Sdn. Bhd. reports, the remote location of the company premises makes on time arrival at work really difficult for its staff. In 
addition, family commitments of some staff were allegedly liable for their poor performance even if they arrived at the workplace on time. Significant Technologies Sdn. Bhd. solved the human resource problem by implementing flexi time and allowing home based operation for selected workers. It also implemented a shorter workdays scheme ( $4 \frac{1}{2}$ working days per week) to enable its staff to have more time to attend to family obligations.

\section{Research and development constraints, solutions and opportunities}

Within the perspective of this study, the research and development constraints are mainly with regards to the unavailability of the complete research and development facilities as the workplace. A solution would be to collaborate with the universities or research Centre. However, Grant Recipients with collaborators from universities and research institutes complained of lack of commitment for commercialization activities (e.g. scaling up and advisory services) from the collaborators. Such complaints are common due to the different business models of the entities concerned. A review of how to create better university-industry interaction is timely so that facilities invested by the government could be optimized accordingly. Reestablishing the teaching company scheme could be considered whereby industrial research and development problems are treated as a postgraduate research project to be jointly supervised by the university and the industry. However, the issue of ownership of intellectual property needs to be resolved accordingly.

\section{Managerial competencies}

The researchers were able to classify managerial competencies into 3 distinct groups: (1) spiritual competencies, (2) core competencies, and (3) basic competencies. These competencies should be viewed form an integrated perspective for technology based companies to be able to compete effectively.

The first competency is related to spiritual. We observe most companies operated by Muslim entrepreneurs have tendencies to incorporate strong religious based value system as part of the organizational culture. Among the companies with such orientation include Company E, Company G, Company J, Company D and Company C.
The second level is known as core competence as it is the one that differentiates the company from the others. A number of companies demonstrate high level of commitment for technological leadership as in the case of Company $\mathrm{K}$ and Company $\mathrm{C}$. In addition, some of the companies a positioning themselves to become total solution providers within the industrial domain they are located in. Examples of such companies include Company $\mathrm{C}$ for organic composting and plant enhancement, Company $\mathrm{K}$ for telematics and Company D for the complete spectrum of orchid propagation to export market development. In addition, some companies show focused in developing business intelligence capabilities from using media to understand what competitors are doing (Company B) to patent road mapping and having dedicated personnel to develop a technology roadmap (Company C). Finally, there is one company (Company $\mathrm{C}$ ) that embraces the knowledge management culture in order to be a learning organization. High levels of information technology infrastructure with knowledge repository systems coupled with a forward planning set of documentation (10-year strategic planning blueprint) makes Company $\mathrm{C}$ stand out as the company with incomparable core competences. Finally, the basic competence is the foundation for the other two types of competences. Among those which we were able to identify include the following: (1) extensive local and international networks; (2) positive characteristics/traits and experience; (3) ability to commercialize effectively; (4) workforce optimization; and (5) ability to identify value added activities (e.g. R\&D) in the value chain.

\section{Value added activities over time}

The value created by the firm changes over time, mostly due to innovations and improvements implemented by the firm. Specifically, value creation increases when these innovations increase the consumer's willingness to pay (for instance, when the quality of the product improves) or reduce the cost of supply (e.g. as a result of adoption of alternative distribution channels such as the Internet).

Based on the aforementioned premise, companies will normally start a new S-curve once they are in the maturity stage of the S-curve (refer Figure 3). Based on Figure 3, the S-curves if plotted over time will show higher value added activities of there is an increment in the trajectories. We believe that the 
Malaysian companies studied which have shown capability to show positive trajectories of their Scurves include the following: (1) after incorporation in 1996, Company C started off with the development of mycorrhiza fungi which has a symbiotic association with the roots of a vascular plant, based on technology from UPM. This success was followed by the development of environmentally-friendly microbial based pesticides with the formulation of Metaxorb $\AA$, specifically targeting Rhinoceros Beetles which threaten the palm oil industry (low value).

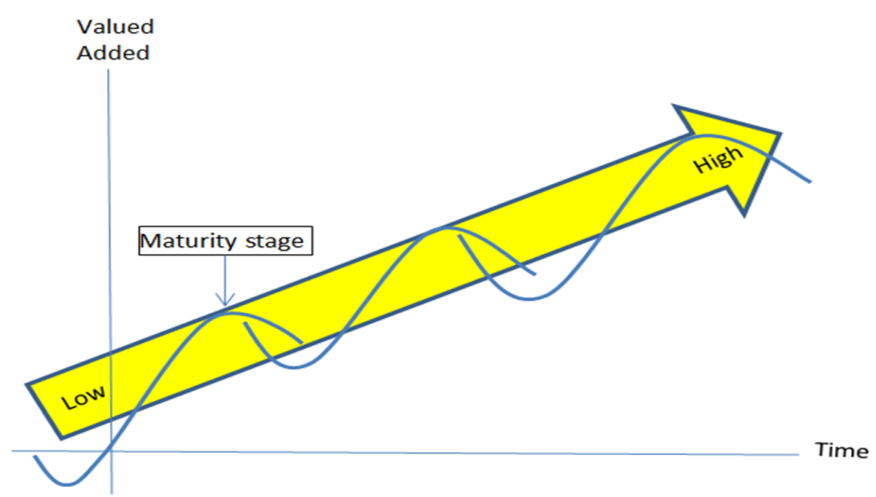

Fig. 3. Trajectories of S-curves

From this platform, Company $\mathrm{C}$ ventured into composting technologies using microbes for empty fruit bunches and other agricultural wastes such as padi wastes (moderate value) and is currently moving towards bioreactor technology to cultivate and extract the active ingredients of traditional herbs such as Tongkat Ali and Ginseng (high value). (2) Company E started off in 1997 as a trading company (low value) and then ventured into producing halal soft gel (moderate value) using gelatin imported from Pakistan. They subsequently converted the gelatin waste to cosmetic products using nano technology in collaboration with the Faculty of Pharmacy of UiTM (high value). (3) Company M ventured from integrated recycling company (low value) to plastic resin (moderate value) and diesel and new coal (high value). (4) Company G developed a new product line call ICON (high value) which is a smart home networked device after developing the optical fiber channel doubler (low value).

\section{Discussion}

Over time, the technologies companies will acquire higher level of managerial competencies which will enable them to create more values from both the customers and stakeholders' perspectives. Only a few companies demonstrate capability to continuously improve their performance. These companies have the ability to migrate from competitive advantage to comparative advantage strategies and create a "positive-sloped value trajectory" based on a series of S-curves over time (refer Figure 4.1). These companies have the fundamentals to be another Toyota in a few years as per the following case study by Lieberman and Balasubramanian (2007, p. 10-11):

Like all firms, Toyota transforms resource inputs, including labor, capital and materials, into useful outputs. From one period to the next, the economic value created by Toyota increases if the company produces the same output with less input (or equivalently, more output with the same level of input). For example, assume that Toyota produces one million cars in a given year; then in a later year, Toyota produces the same number cars of identical quality but requires $10 \%$ less capital, labor and materials Scerri, M. (2012).. In this case, Toyota's resource efficiency ("Total Factor Productivity") has grown by $10 \%$. While Toyota's output has not changed, the firm has freed up resource inputs that can be used elsewhere in the economy. Alternately, assume that Toyota produces one million cars in the first year, and one million cars of higher quality in the second year, using the same amount of labor, capital and materials input in both years. Consumers are willing to pay $10 \%$ more for Toyota's cars in the second year because of their enhanced quality. In this case, as in the previous example, Toyota has created $10 \%$ more economic value. If prices are recorded and interpreted correctly, in both cases Toyota will also be found to have achieved a $10 \%$ gain in the efficiency of resource-use. These examples show that incremental value creation by the firm is equivalent to gains in total factor productivity. Both are achieved through resource savings, quality improvements, or some combination."

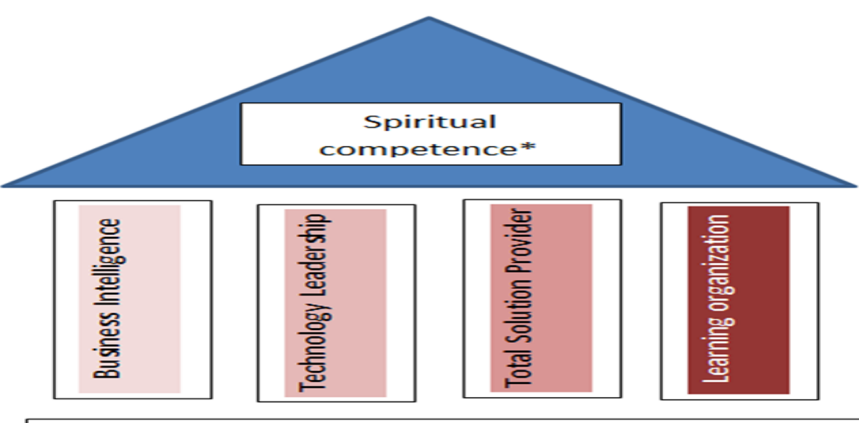

Basic Competence 
Fig. 4. The House of Competence

(*note: Relevant for most Muslim-owned companies)

As mentioned earlier, the three types of competencies should be viewed from an integrated perspective. Based on Figure 4, we propose the house of competencies with the spiritual competencies as the roof that protects the house, the core competencies are the pillars for the house to stand strong and the basic competencies is the foundation of the house.

Finally, Figure 5 revisited the concept of time for the value creation and managerial competencies, companies which are able to progress from basic to advanced value creation stages over time normally demonstrate high level of managerial competencies as well. Again, the concept of integration must be observed as the managerial competencies must function together to achieve higher value creation. Among the companies which follow this progression are Company C, Company E, and Company M. These are the few companies that show much promise to become global players in the near future.

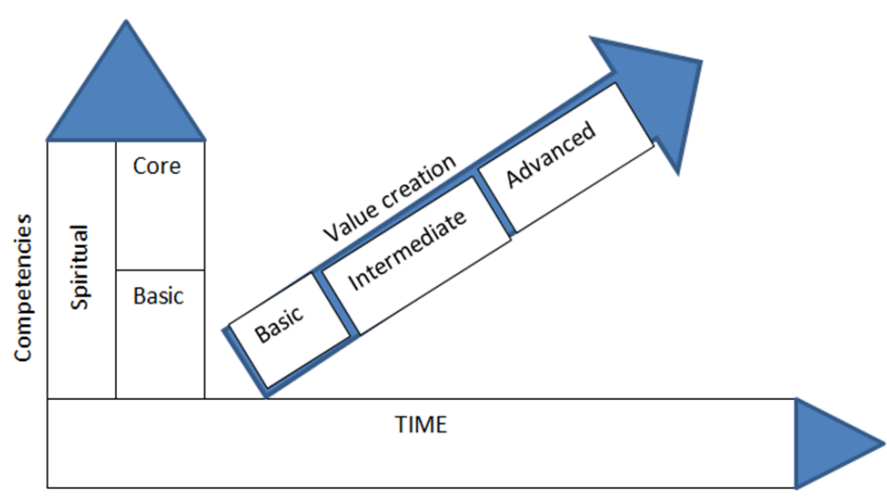

Fig. 5. Competencies and Value Creation Mapped Over Time

We conclude that the resource-based theory of organizational competitiveness are evident albeit among a few small technology-based companies in Malaysia suggesting that these small companies' underlying unique competitive advantage could be enhanced if they seek to become learning organizations.

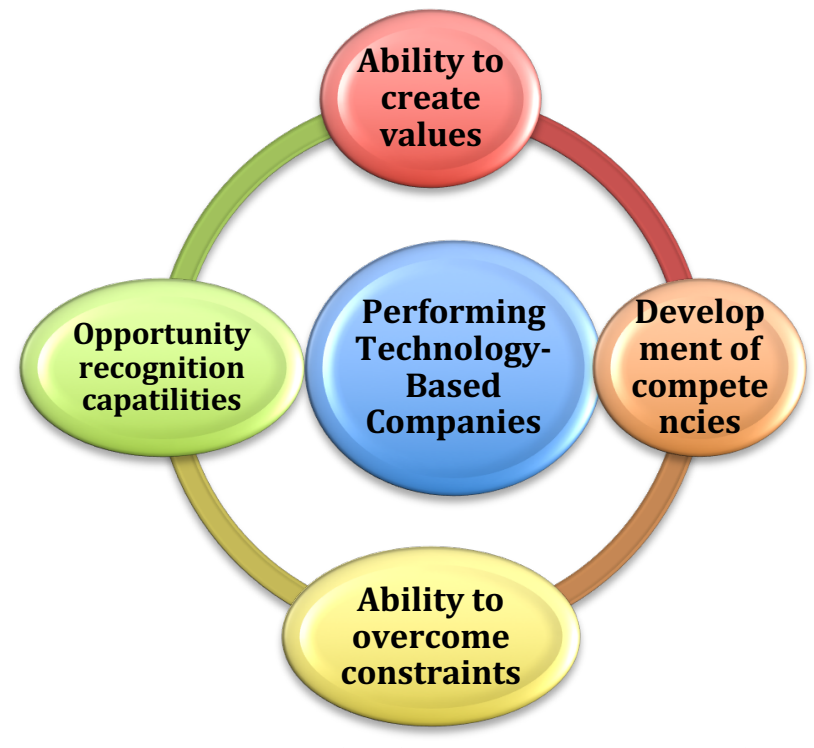

Fig. 6. The Four Enablers of Performing Technology-Based Companies

\section{Acknowledgement}

The authors wish to express their gratitude and appreciation to the Malaysian Technology Development Corporation for the funding of this research through Universiti Teknologi Malaysia.

\section{References}

Adebowale, B.O.A. (2012). 'Innovation policies institutions and performance: why Malaysia overtook Nigeria in the oil palm industry', Int. J. Technological Learning, Innovation and Development, Vol. 5, Nos. 1/2, pp.126-157.

Barney, J. B. (2001). Resource-based theories of competitive advantage: A ten-year retrospective on the resource-based view. Journal of management, 27(6), 643-650.

Beckmann, M. \& Hielscher, S. (2010). Value Creation, Management Competencies, and Global Corporate Citizenship: An Ordonomic Approch to Business Ethics in the Age of Globalization, Journal of Business Ethics, 94: 265-278.

Down, S. (1999). Owner-Manager Learning in Small firms, Journal of Small Business and Enterprise Development, 6(3): 267-80.

Edgar, W.B. \& Lockwood, C. (2008). Organizational Competencies: Clarifying the Construct. Journal of Business Inquiry: Research, Education, and Application, 7(1): 21-32.

Grant, R.M. (1991). The Resource-Based Theory of Competitive Advantage: Implications for Strategy Formulation. California Management Review 33 (3): 114-135.

Greenbank, P. (2000). Training micro-business owner-managers: a challenge to current approaches, Journal of European Industrial Training, 24(7): 403.

Kelliher, F. \& Reinl, L. (2009). Points Of View A Resource-Based View Of Micro-firm Management Practice, Journal Of Small Business And Enterprise Development, 16 (3): 521-532.

Lavie D. (2006). The Competitive Advantage Of Interconnected Firms: An Extension Of The Resource-Based View, Academy Of Management Review, 31(3): 638-658.

Lieberman M. B., Balasubramanian N. (2007) Measuring Value Creation and Its Distribution Among Stakeholders Of the Firm. Website: $\mathrm{http}: / / \mathrm{www}$.anderson.ucla.edu/faculty/marvin.lieberman/docs/LiebermanS ubra_VCD.pdf

Miles M.B. and Huberman, M.A. (1994). Qualitative Analysis: An Ezpanded Handbook (2nd ed.). Thousand Oaks, CA: Sage(BARU)

Newbert, S. L. (2007). Empirical research on the resource-based view of the firm: An assessment and suggestions for future research. Strategic Management Journal, 28(20, 121-146.

Nonaka, I. (1995). The Knowledge-Creating Company: How Japanese Companies Create the Dynamics of Innovation: How Japanese Companies Create the Dynamics of Innovation. Oxford university press. 
O’Dwyer, M. \& Ryan, E. (2000). Management development issues for owners/managers of micro-enterprises, Journal of European Industrial Training, 24(6): 345 .

O'Malley, P. (1998). Value Creation and Business Success, The Systems Thinker, 9(2). Website:

http://www.pegasuscom.com/levpoints/valuecreate.html.

Peteraf M.A. (1993). The Cornerstones Of Competitive Advantage: AresourceBased View, Strategic Management Journal, 14. Website:

https://faculty.fuqua.duke.edu/ moorman/GeneralMills/Section2/Section2 Documents/Peteraf.pdf
Ray, G., Barney, J. B., and Muhanna, W. A. (2004). Capabilities, business processes, and competitive advantage: Choosing the dependent variable in resource-based view. Strategic Management Journal, 25, 23-37

Scerri, M. (2012). 'The introduction of the systems ofinnovation approach in economics curricula', Int. J. Technological Learning, Innovation and Development, Vol. 5, Nos. 1/2, pp.12-27.

Wade, M. and Hulland, J. (2004), "The Resource-Based View and information Systems Research: Review, Extension, and Suggestions for Future Research,” MIS Quarterly, 28, 1 (March), 107-142 (BARU)

Wernerfelt B. (1984). A resource-based view of the firm. Strategic Management Journal, 5(2): 171-180. 